\title{
Mutagenicity of hydroxyurea in lymphocytes from patients with sickle cell disease
}

\author{
André Salim Khayat ${ }^{1}$, Adriana Costa Guimarães ${ }^{1}$, Plínio Cerqueira Cardoso ${ }^{1}$, \\ Patrícia Danielle Lima de Lima ${ }^{1}$, Marcelo de Oliveira Bahia ${ }^{2}$, Lusânia M. Greggi Antunes ${ }^{3}$ \\ and Rommel Rodríguez Burbano ${ }^{1}$ \\ ${ }^{1}$ Universidade Federal do Pará, Centro de Ciências Biológicas, Departamento de Biologia, \\ Belém, PA, Brazil. \\ ${ }^{2}$ Universidade Federal do Pará, Centro de Ciências Biológicas, Departamento de Patologia, \\ Belém, PA, Brazil. \\ ${ }^{3}$ Faculdade de Medicina do Triângulo Mineiro, Deptartamento de Ciências Biológicas, \\ Uberaba, MG, Brazil.
}

\begin{abstract}
Hydroxyurea is commonly used in the treatment of myeloproliferative diseases and in patients with sickle cell disease (SCD). The use of this antineoplastic agent in patients with SCD is justified because of the drug's ability to increase fetal hemoglobin levels, thereby decreasing the severity of SCD. However, high doses or prolonged treatment with hydroxyurea can be cytotoxic or genotoxic for these patients, with an increased risk of developing acute leukemia. This danger can be avoided by monitoring the lymphocytes of patients treated with hydroxyurea. Cytogenetic tests are important endpoints for monitoring the physiological effects of physical and chemical agents, including drugs. In this work, we assessed the genotoxicity of hydroxyurea in short-term cultures of lymphocytes from SCD patients. Hydroxyurea was not cytotoxic or genotoxic at the concentrations tested in the G2 phase of the cell cycle. These results support the use of hydroxyurea in the treatment of SCD, although further work is necessary to understand the effects of this drug in vivo.
\end{abstract}

Key words: hydroxyurea, sickle cell disease, mutagenesis.

Received: December 9, 2002; Accepted: August 12, 2003.

\section{Introduction}

Hydroxyurea (HU) is an antineoplastic agent that acts on the enzyme ribonucleotide reductase enzyme to inhibit the conversion of ribonucleotides into deoxyribonucleotides, thereby limiting DNA biosynthesis. By preventing impeding deoxyribonucleotide synthesis, $\mathrm{HU}$ acts as a cytotoxic and antineoplastic agent that specifically affects the $\mathrm{S}$ phase and interrupts the cell cycle in the G2 and S phases (Yarbro, 1992; Donehower, 1992).

This mechanism has led to clinical applications in a variety of infect-contagious diseases, neoplasias and hematological disorders (De Vita et al., 1997; Mayhew et al., 1999; De Montalembert, 1999; Melo et al., 2000). Hydroxyurea is useful for the treatment of patients with sickle cell anemia, a hemolytic anemia caused by erythro-

Send correspondence to Rommel Rodríguez Burbano. Universidade Federal do Pará, Campus Universitário do Guamá, Centro de Ciências Biológicas, Departamento de Biologia, Laboratório de Citogenética Humana, Av. Augusto Correa 1, 66075-900, Belém, PA, Brazil. E-mail: rommel@ufpa.br. cyte deformation (sickling) (Reid et al., 1995), since it increases fetal hemoglobin production $(\mathrm{HbF})$, thereby boosting the absolute number and proportion of HbF-carrying reticulocytes and elevating the $\mathrm{HbF}$ concentration in individual cells. The increase in HbF reduces the tendency of abnormal hemoglobin ( $\mathrm{HbS}$ ) to polymerize and decreases the formation of abnormal cells characteristic of sickle cell anemia (Donehower, 1992).

Despite its widespread clinical use, HU can damage DNA (genotoxic action) and produce gene and chromosomal mutations (Donehower, 1992). In this work, we assessed the cytotoxicity (mitotic index) and the genotoxicity (chromosomal aberrations and polyploidy) of HU in lymphocytes from sickle cell anemia patients treated with this compound.

\section{Materials and Methods}

Peripheral blood samples were collected from eight patients (five men and three women) by venipuncture. The 
subjects were carries for sickle cell anemia who were not yet on HU therapy, but who began using HU immediately after blood collection. The study protocol was approved by the Medical Ethics Committee of the Pará State Hemotherapy and Hematology Center (HEMOPA).

Lymphocytes isolated from the blood samples were cultured at $37{ }^{\circ} \mathrm{C}$ in HAM-F10 culture medium, complemented with streptomycin $(10 \mu \mathrm{g} / \mathrm{mL})$, penicillin $(5 \mu \mathrm{g} / \mathrm{mL}), 19.2 \%$ fetal calf serum and $4 \%$ phytohemagglutinin, the latter used as a lymphocyte mitotic stimulator.

Hydroxyurea was obtained from $500 \mathrm{mg}$ gelatinous capsules of Hydrea ${ }^{\circledR}$, the contents of which were prepared in bi-distilled sterile water.

The G2 phase of the cell cycle is the most suitable phase for accessing the mutagenicity of $\mathrm{HU}$, because this drug is S-phase dependent and generally inhibits the cell cycle when added to phases prior to G2 (Lindenhahn and Schubert, 1983). Lymphocytes were exposed to HU $(50 \mu \mathrm{g} / \mathrm{mL}$ and $100 \mu \mathrm{g} / \mathrm{mL}) 69 \mathrm{~h}$ after the onset of mitogenesis in complete HAM-F10 medium. After $1 \mathrm{~h}$, the cells were incubated with colchicine $(2 \mathrm{~h})$ to arrest them in metaphase, and then fixed with Carnoy fixative (Acetic acid: Methanol 1:3 v/v) .Peripheral blood lymphocytes in metaphase were prepared essentially as described by Moorhead et al. (Moorhead et al., 1960), with modifications introduced by Human Cytogenetics Laboratory. at UFPA

The preparations were examinated by light microscopy to asses the structural or numerical chromosomal alterations present (Rabello-Gay et al., 1991).

The frequency of chromosomal aberrations (100 metaphases/culture) and the mitotic index (number of methaphases in 2,000 lymphoblasts/culture) of cells treated with HU (50 and $100 \mu \mathrm{g} / \mathrm{mL}$ ) were determined, and compared with their respective control groups (lymphocytes cultures not exposed to $\mathrm{HU}$ ).

The frequencies of aberrations in lymphocytes treated with HU compared to the non treated controls were compared using Student's T-test (Ayres et al., 2000).

The mitotic indices of HU treated and non-treated lymphocytes were compared using the F test (ANOVA). The level of significance was set at $\mathrm{p}<0.05$ for all analyses (Ayres et al., 2000).

\section{Results and Discussion}

In recent years, HU has become one of the most widely used drugs for the treatment of myeloproliferative disorders and some forms of solid tumours, as well as other non-malignant diseases such as sickle cell anemia (Kantarjian et al., 1993; Hehlmann et al., 1994; O’Brien et al., 1996).

In a pilot study using lymphocytes from healthy individuals (non SCD), high concentrations of $\mathrm{HU}$
$(>100 \mu \mathrm{g} / \mathrm{mL})$ caused severe cytotoxicity in all phases of the cell cycle (unpublished results in this paper). This extensive damage made it impossible to access chromosomal alterations, while lower concentrations $(<50 \mu \mathrm{g} / \mathrm{mL})$ caused no significant chromosomal aberrations. Based on these findings, we examined the effects of $\mathrm{HU}$ on peripheral blood lymphocytes from SCD patients. Two concentrations of $\mathrm{HU}(50$ and $100 \mu \mathrm{g} / \mathrm{mL})$ were tested in the G2 phase of the cell cycle.

The mitotic index of HU-treated lymphocytes was not significantly different from that of non tested cells (Table 1). This result may reflect the S-phase dependency of the drug and patients' hematological condition that the lymphocytes did not proliferate as much as expected. It is also possible that proliferation may have occurred only in cells resistant to the effects of HU.

Analysis of the chromosomal alterations in metaphasic lymphocytes from anemic patients (Figure 1) also showed significant differences compared to the controls (Table 2). Curiously, non-treated lymphocytes from patients IV, VI, and X contained from 2-3 chromosomal breaks, suggesting possible endogenous chromosomal instability in these individuals, which may indicate that these patients should not to be treated with this drug. Such alter-

Table 1 - Mitotic indexes in cultured peripheral blood lymphocytes from of SCD patients.

\begin{tabular}{llll}
\hline \multirow{2}{*}{ Patients } & \multicolumn{3}{c}{ Hydroxiurea $(\mu \mathrm{g} / \mathrm{mL})$} \\
\cline { 2 - 4 } & $0^{1}$ & 50 & 100 \\
\hline II & 1.95 & 1.2 & 1.05 \\
III & 1.65 & 2.1 & 0.75 \\
IV & 1.9 & 1.35 & 1.6 \\
VI & 0.55 & 0.55 & 0.4 \\
VII & 1.6 & 1.35 & 1.75 \\
VIII & 0.55 & 0.3 & 0.6 \\
IX & 0.45 & 0.6 & 0.3 \\
X & 1.6 & 0.9 & 0.7 \\
\hline
\end{tabular}

${ }^{1}$ Control.

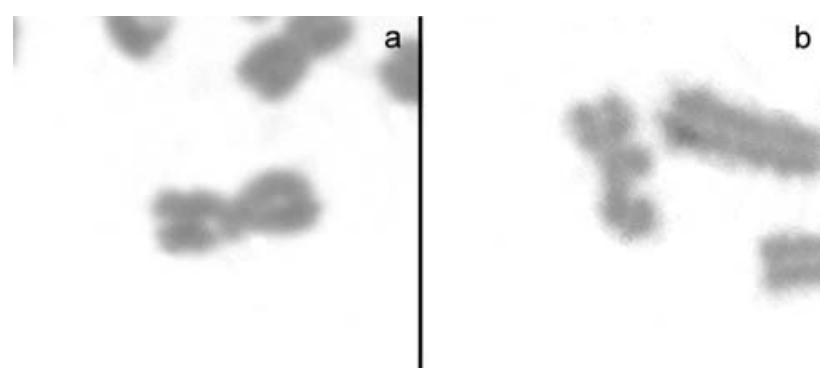

Figure 1 - Chromosomal alterations in metaphasic lymphocytes from anemic patients: (a) chromatid gap in chromosome 1 and (b) chromatid break in chromosome 16 . 
Table 2 - Number and type of chromosomal alterations in metaphase in cultured peripheral blood lymphocyte from SCD patients.

\begin{tabular}{lccc}
\hline Patients & \multicolumn{3}{c}{ Hidroxyurea $(\mu \mathrm{g} / \mathrm{mL})$} \\
\cline { 2 - 4 } & $0^{1}$ & 50 & 100 \\
\hline II & $2 \mathrm{ctg} 1 \mathrm{pol}$ & $8 \mathrm{ctg}$ & $6 \mathrm{ctg}$ \\
III & $5 \mathrm{ctg}$ & $3 \mathrm{ctg}$ & $2 \mathrm{ctg}$ \\
IV & $3 \mathrm{ctb} 2 \mathrm{ctg}$ & 0 & 0 \\
VI & $2 \mathrm{ctb} 2 \mathrm{ctg}$ & $1 \mathrm{ctb} 2 \mathrm{ctg}$ & $1 \mathrm{ctb}$ \\
VII & $1 \mathrm{ctg}$ & 0 & $1 \mathrm{ctg}$ \\
VIII & 0 & 0 & 0 \\
IX & 0 & 0 & 0 \\
X & $2 \mathrm{ctb} 2 \mathrm{ctg} 1 \mathrm{csg}$ & $1 \mathrm{ctb} 2 \mathrm{ctg}$ & $3 \mathrm{ctb}$ \\
\hline
\end{tabular}

${ }^{1}$ Control; ctg-chromatic gap; pol-polyploidy; ctb-chromatic break; csgchromosomal gap.

ations were not seen in cells from healthy individuals (unpublished observations).

In conclusion, these results support use of $\mathrm{HU}$ in the treatment of SCD since no adverse cytotoxic or genotoxic effects were observed under the conditions used here. However studies in vivo are required to confirm these data.

\section{Acknowledgments}

The authors thank to Glorita Santos for their support during this work, and HEMOPA for providing the samples. K.A.S. was supported by a CAPES scholarship.

\section{References}

Ayres M, Ayres Jr M, Ayres DL and Santos AS (2000) Bioestat 2.0: Aplicações estatísticas nas áreas das ciências biológicas e médicas. 2nd ed. Sociedade Civil Mamirauá, CNPq, Belém, 262 pp.

De Montalembert M (1999) Hydroxyurea and other agents stimulating synthesis of fetal hemoglobin. Path Biol 47:55-58.

De Vita VT, Hellman S and Rosenberg AS (1997) Cancer: principles and practice of Oncology. 5th ed. Lippincott Raven Publishers, New York, 448 pp.

Donehower RC (1992) An overview of the clinical experience with hydroxyurea. Semin Oncol 19(Suppl. 9):11-19.
Hehlmann R, Heimpel H, Hasford J, Kolb HJ, Pralle H, Hossfeld DK, Queiber W, Löffler H, Hochhaus A, Heinze B, Georgii A, Bartram CR, Griebhammer M, Bergmann L, Essers U, Falge C, Queier U, Meyer P, Schmitz N, Eimermacher H, Walther F, Fett W, Kleeberg UR, Käbisch BA, Nerl C, Zimmermann R, Meuret G, Tichelli A, Kanz L, Tigges FJ, Schmid L, Brockhaus W, Tobler A, Reiter A, Perker M, Emmerich B, Verpoort K, Zandovich R, Wusson PV, Prümmer O, Thiele J, Buhr T, Carbonell F, Ansari H and German CML study group (1994) randomized comparison of interferon-a with busulfan and hydroxyurea in chronic myelogenous leukemia. Blood 84:4064-4077.

Kantarjian HM, Deisseroth A, Kurzrock R, Estrov Z and Talpaz M (1993) Chronic myelogenous leukemia: a concise update. Blood 82:691-703.

Lindenhahn M and Schubert I (1983) On the origin of hydroxyurea-induced chromatid aberrations in G2 chromosomes with BrdUrd in only one of the sister chromatids. Mutat Res 108:301-316.

Mayhew CN, Phillips JD, Greenberg RN, Birch NJ, Elford HL and Gallicchio VS (1999) In vivo and in vitro comparison of the short-term hematopoietic toxicity between hydroxyurea and trimidox or didox, novel ribonucleotide reductase inhibitors with poential anti-HIV-1 activity. Stem Cells 17:345356.

Melo EJT, Mayerhoffer RO and Souza W (2000) Hydroxyurea inhibits intracellular Toxoplasma gondii multiplication. FEMS Microbiol Lett 185:79-82.

Moorhead PS, Nowell PC, Mellmam WJ, Battips DM and Hungerford DA (1960) Chromosome preparations of leukocytes cultured from human peripheral blood. Expi Cell Res 20:613-616.

O'Brien S, Kantarjian H and Talpaz M (1996) Practical guidelines for the management of chronic myelogenous leukemia with interferon alpha. Leuk Lymphoma 23:247-252.

Rabello-Gay MN, Rodrigues MAR and Monteleone-Neto R (1991) Mutagênese, teratogênese e carcinogênese: critérios de avaliação. Sociedade Brasileira de Genética, Ribeirão Preto, 246 pp.

Reid CD, Charache S and Lubin B (1995) Management and therapy of sickle cell disease. NIH Publications, Bethesda, 115 pp.

Yarbro JW (1992) Mechanism of action of hydroxyurea. Semin Oncol 19(Suppl. 9):1-10. 